\title{
The Effects of Services Marketing Mix Elements on Brand Equity and Customer Response of Tourists Hotels in the East Coast of Sri Lanka
}

\author{
Mohamed Ismail Mujahid Hilal
}

\begin{abstract}
The purpose of the study was to examine the effect of the elements of extended service marketing mix of the east coast hotels in Sri Lanka on the creation of the brand equity and how that brand equity plays a mediating role in customers' response. The study was quantitative in nature. Survey methodology was adopted. 163 tourists arriving in Sri Lanka who stayed in the hotels in the East Coast of Sri Lanka were surveyed. The questionnaire was used to collect the data. Smart PLS 3 was used to analyze the data. Findings suggest that people, process, physical evidence and marketing communication elements have an effect on the brand equity and in turn positively influence the customer response towards the hotel. Findings also suggest that brand equity of these hotels is partially mediating between extended marketing mix elements and customer response to the hotels. However, marketing communication is not significantly contributing to brand equity. Hoteliers in the region can focus on the people, process and physical evidence to improve their hotel performance as it also contributes to the customer responses towards hotels.
\end{abstract}

Keywords: Service marketing mix, people, process, physical evidence, brand equity, customer response

\section{INTRODUCTION}

The tourism sector in Sri Lanka is growing dramatically contributing to the Sri Lankan economy in terms of Gross Domestic Production and employment. While the tourism sector is growing, there is a necessity of examining the impact of service marketing mix elements on brand equity and how that brand equity leads to customer response in the hotel industry. Sri Lanka received over 2.3 million arrivals in 2018. This was a 10 percent increase compared to the year 2017. In the case foreign exchange earnings, Sri Lanka's earnings increased by 18.5 percent in 2016. The employment generated in the sector irrespective of direct and indirect increased by 5.1 percent in the year 2016 (Annual Statistical Report - 2016).

Marketing mix strategies are playing a pivotal role in achieving market share and in enhancing business performance. Although studies reveal that there are seven Ps in the marketing mix of service organizations, the extended marketing mix such as people, process and physical evidence (Wirtz and Lovelock, 2016) along with marketing communication of the hotel industry are the key components of the service marketing mix. Hence, this study focus on these extended marketing mixes along with

Revised Manuscript Received on September 10, 2019.

Mohamed Ismail Mujahid Hilal (PhD), Senior Lecturer in Marketing Management, Faculty of Management and Commerce, South Eastern University of Sri Lanka, Oluvil, Sri Lanka

(E-mail: mujahidh@seu.ac.lk) marketing communication of hotels. This is because of the fact that marketing mix positively influences on the brand equity (Abril and Canovas, 2016).

Brand equity is "the differential effect that brand knowledge has on consumer response to the marketing that brand" (Keller, 2013). Brand knowledge consists of brand awareness and brand image (Erdem et al., 2006). Brand knowledge always impacts on the consumer purchase intention which is customers' response (Erdem et al., 2006). The marketing mix elements positively influence on the brand equity (Aghaei et al., 2013). This means that when a brand of hotels has a higher level of equity, brand awareness for the particular hotel brand is recalled and recognized (Huang and Sarigollu, 2012). Brand image is another important component of brand equity. In the case of the hotel industry, functional attributes of the hotels are associated with the brand image (Horng et al., 2012). Many studies find that brand image positively exerts an influence on the customers' attitude of paying higher prices for brands (Keller, 1993; Cretu \& Brodie, 2007). The brand image created also improves brand equity for any brands that are marketed (Yoo et al., 2000). When there are increased brand awareness and brand image, customers are with commitment directed towards customer response which is purchase intention (Erdem et al., 2006).

In the hotel industry in Sri Lanka, brand equity generated from the elements of the marketing mix is expected to create customer response in terms of purchase intention and creating word of mouth. Liu et al., (2017) indicate that the customer based brand equity of the luxury hotels causes the brand equity, in turn, generate brand attitude and create purchase intention. In addition, Seo and Park (2018) find that social media marketing communication is also influencing on the customers' response in the airline industry mediating through brand equity. This study also finds that there is a positive relationship between brand equity and customer response by way of creating word of mouth and customers' commitment. When looking at the contribution to the economy of the country, there is an opportunity for the destination marketing organizations to improve further the tourism products in terms of marketing. Sri Lanka tourism is growing progressively with the huge assistance of the government of Sri Lanka. Destination marketing organizations need to focus on the branding strategies to promote an attraction as a tourist destination. According to

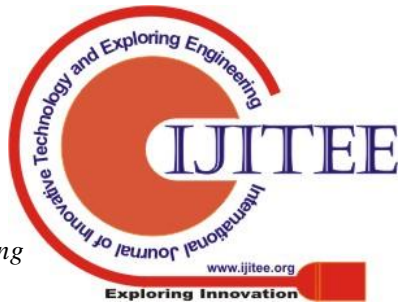


the tourism strategic plan 2017-2020 of Sri Lanka tourist board, Sri Lanka is working on the tourism destination planning and to make them sustainable through facilitating the destination management. Destination management can only possible when evaluating the services of the organizations and services elements need to be modified accordingly.

After the prolonged war, the tourism is picking up in the North East part of the country considerably. Many hotels are operating here on the East coast of Sri Lanka with the objective of maximizing the profits and the performance. The marketing mix elements could be combined together to create effective marketing for a firm (Aghaei et al., 2013). As far as service marketing mix is concerned of the hotels in the East Coast of Sri Lanka, studies are lacking in the areas of the extended services marketing mix, brand equity and its impact on the responses of the customers. Therefore, the research questions are whether the elements of the service marketing mix lead to the brand equity and that influences on the customer response? What is the relationship between extended marketing mix of hotels in the East Coast of Sri Lanka and customer response? What is the role played by brand equity in creating customer response?

In order to address the research questions, the following objectives are formulated. The major objective of the study was to examine the effect of the elements of the extended service marketing mix in the east coast hotels on the creation of brand equity. The specific objectives were to explore the relationship between the elements of the service marketing mix with customers' response and to evaluate the mediating effect of the brand equity elements of the east coast hotels such as brand awareness and brand image on the customers' response. Final objective was to suggest strategies to improve the service marketing mix for hotels in the East Coast of Sri Lanka.

\section{REVIEW OF LITERATURES AND HYPOTHESES DEVELOPMENT}

Employees' skills are also key for creating brand equity and to influence on the purchase intention of customers. Here, employees' skills means customer service skills including building up reputation to the organization among people by way of effectively serving to the customers, creating the culture of customer service within the organization and technical and functional satisfaction of customers. This influences on the customer loyalty which is part of customer-based brand equity (Abu-ELSamen et al., 2011). As the employees are considered as the major part of the people elements of the extended marketing mix, employees' commitment is also one of the important components that influence the customer responses. This infers about customers' willingness to make the payment, their faithfulness, advocacy and altruism (Jones et al., 2010).

Further, in the case of marketing communication, online reviews through social media also make an impact on consumer responses. This happens when managers actively engage in monitoring online reviews and take corrective actions instantly. This paves the way for managers to communicate with potential customers and it shows that managers are on the side of the customers. This helps customers to act towards the service organizations (Xie et al., 2016). Findings of a study conducted on the effects of service experience on customer responses to a hotel chain (Bravo et al., 2019) indicate that service perception regulates customer satisfaction by the feelings given by the customers towards hotels. This also affects the customer attitudes towards hotel brands and that influence on the customer intention to revisit to the hotels (Bravo et al., 2019).

Employees of the service organization may further influence the customers' response by the emotions that they display to the customers. Particularly, the front line employees' attribution may induce the positive behavioral response of the customers that are buying intention (Albrecht et al., 2016). It is also found that language spoken by the employees during the customer interaction at the service place impact positively on the interaction quality and subsequently, contribute to the service quality. This, in turn, have an impact on the customer response in terms of generating word of mouth and creating customer loyalty (Zolfagharian et al., 2018).

\section{PEOPLE ELEMENTS (EMPLOYEES)}

Internal marketing is crucial for service firms particularly for firms involved in tourism and hospitality businesses. Internal marketing is also contributing more to the people element of the extended marketing mix of service. Employees working at the hotel are imperative for business success. Customers measure the employees' performance and determine the quality of service offered by tourists' hotels. Internal marketing contributes to the creation of a long term relationship with customers (Caruana and Calleya 1998). Although the people element of the extended marketing mix covers employees' selection, training and motivation of them, this study attempts to get the perception of customers about employees who work in the hotels who respond to the customers in relation to the services. Employees are also playing a pivotal role in the hospitality industry owing to the intangibility and inseparability nature of service business (Papasolomou and Vrontis, 2006). People element of the extended marketing mix is essential as this strong impact on the service quality (Lovelock, 2016). Further, employees' aspects of internal marketing are also contributing to both service quality and new service performance (Hernandez and Miranda, 2011). This also implies that internal marketing will have an impact on the customer response as service performance will also be enhanced and that influence on service quality. Internal marketing is the prime injector for achieving the right behavior of employees thereby enable corporate branding (Papasolomou and Vrontis, 2006).

According to a research (Yang and Coates, 2010) explains that employees should be competent enough to serve the customers which means that employees are likely to have knowledge and skills including both professional and managerial skills. When employees are with those skills, the reliability of service will be stretched.

Blue Eyes Intelligence Engineering

\& Sciences Publication 
Service quality should be enhanced as it has a powerful Reliability is one of the important aspects of service marketing influencing more on the purchase intention of the customers (Choudhury, 2013). It was also emphasized that when service quality is good at the service organizations and customer satisfaction will enable customers to recommend to others and that will further increase the purchase intention and loyalty (Sivadas and Prewitt, 2000). Moreover, it is to witness that people element of the extended marketing mix will lead to the brand equity of the hotel with help of loyalty created and it may associate with customer response. It is also understood that the brand equity is different for service and product. In a service setting, consumers create brand equity during their experience with service employees and self-service technology (Kimpakorn and Tocquer, 2010). Therefore, the researcher proposes the following hypotheses;

$\mathrm{H}_{1}$ : People element of the hotels on the east coast of Sri Lanka contributes to brand equity of the hotel brands

$\mathrm{H}_{1 \mathrm{a}}$ : People element of the hotels on the east coast of Sri Lanka positively affect the customers' response

\section{PROCESS ELEMENT}

Service process and its design are vital for service organizations. Service design builds up the brand image for organizations and consequently, it results in value addition and improves the quality of service (Larsen et al., 2007). Managing waiting time for a service of any nature needs to Hence, managers should know about the service time taken for a customer. In the event of failing to understand the waiting time of the service process, managers may lose the benefits of innovative technology. Hence, it was found that designing the service flexibly is effective when having high demands (Sheu et al., 2003). Service design should be implemented along with the overall strategy of the organizations. When the service design is not matched with the overall strategy, it may be difficult for the service organizations to provide customer satisfaction to the customers (Mager, 2004). Therefore, it negatively affects the service organization lies on the adoption of market orientation, having effective service design and implementing a good service climate (Kostopoulos et al., 2012). For service design to be effective, managers give priority for service blueprinting. However, it may not be effective until the employees in the organization follow and implement it (Bitner et al., 2012).

Berman and Evans (2012) point out that designing factors such as the location of the business, style of selling, way of merchandising, parking and entertainment at the business organizations make the organization attractive to customers. Customer should have excellent service experience in the service settings. If not, just an entertainment along with appealing exterior will not cause customer loyalty (Beltagui and Candi, 2018). In contrast, when the designing is effective and customers are attracted then it creates brand equity and may positively impact on the customer response. Therefore, service operation should be designed in a way that satisfies the customers and service operation could be influence on customer loyalty (Wong and Sohal, 2003). be carefully looked at in order to make the service efficient. the customer response. This is due to the fact that success of

blended with effective communication that may improve customer satisfaction (Ramanathan et al., 2017).

In a service organization, implementation of the service recovery system is also vital. A service recovery system should include skills of employees and their autonomous functions in the firm, the way of identifying the root cause of the problem and how far the solution matches with customer needs (Contiero et al., 2016). However, a service system with excellent quality may have an impact on the service experience of the customers and in turn on brand equity and customer response. This may be a result of quality environment established in the organizations. This further positively affect the employees enabling them to work (Smith et al., 2017). Customers are playing an important role in shaping the experience and creating core value for the service (Andreassen et al., 2016).

Service environment is very much essential to create brand equity. This is due to the fact that pleasant service process with attractions in the store environment will lead to impulse buying (Mattila and Wirtz, 2008). Service environment should match with customer expectations. Hence, it is necessary to focus on the factors causing pleasure to the customers. This may be an outcome of the effect of arousal due to the service environment which is excited. Thus, a service environment should have valence by which customers react towards the service organization (Wirtz et al., 2007). Employees' interaction with customers in the service environment will also contribute to the image of the organizations as a component of brand equity ( $\mathrm{Hu}$ and Jasper, 2006). Service process mainly focuses on the service process design and the environment in which service is taking place. When the customers are looking at the service process as attraction and create pleasant behavior for them, which will have an impact on the organization brand equity and in turn, will influence on the customer response. Thus, the researcher hypothesizes the following hypotheses.

$\mathrm{H}_{2}$ : Process element of the hotels on the east coast of Sri Lanka contributes to the brand equity of hotels' brand.

$\mathrm{H}_{2 \mathrm{a}}$ : Process element of the hotels on the east coast of Sri Lanka positively affect the customers' response

\section{PHYSICAL EVIDENCE}

According to Bitner (1992), the physical environment of service will have an impact on the customers' response. Bitner (1992) explained that the physical environment of the service comprises ambient condition, space/functions and signs and symbols of the organization. Ambient condition covers the temperature of the environment, air quality, noise, music, and odor. Space and function include the layout of the organization, equipment used and furnishing of the service place. Signs, symbols, and artifacts include signage, personal artifacts, and style of decor, etc. Service environment along with all physical evidence is important for the service organizations to provide customers a good quality of service and it may create brand equity and customer response. Physical environment has also an impact on the satisfaction of customers (Ali et al., 2013). 
Customers integrate many aspects such as service delivery, service product, and service environment in order to determine the service quality (Rauch et al., 2015). Physical environment characteristics such as color, scene, music, and layout of the service organization are important evidence for the customers to choose the service providers (Oh et al., 2008). Further, Mahmood and Khan (2014) find that service organizations differentiate themselves from competitors and influence on the customer in selecting service organizations by using physical evidence. This was also confirmed that the service environment is one of the important factor influencing on the purchasing decisions (Hanaysha, 2018). Moreover, the service environment is also affecting impulse buying. Of all elements of the service environment, the layout is with the highest effect on impulse buying (Mohan et al., 2013). The environment should be able to cause customers to engage in and induce customers to interact with brands (Sachdeva and Goel, 2015).

The discussion of literature points out that physical evidence comprising ambient conditions of the service organizations, space, and function of the organizations, signs, symbols of the organizations, good interaction with customers motivate customers to do impulse buying and likely to create brand equity. Mukherjee and Shivani (2016) proved that the physical evidence positively contributes to the brand equity. This created brand equity, in turn, influence on the purchase intention of the customers. Therefore, researcher proposes the following hypotheses;

$\mathrm{H}_{3}$ : Physical evidences of the hotels on the east coast of Sri Lanka contributes to the brand equity of the hotels brand.

$\mathrm{H}_{3 \mathrm{a}}$ : Physical evidence of the hotels on the east coast of Sri Lanka positively affect the customers' response.

\section{MARKETING COMMUNICATION}

Marketing communication plays a major role in creating brand equity and in turn influence the customer responses. Marketing communication consists of advertising, public relation, personal selling, and sales promotion. Although marketing communication includes all these elements, social media currently gives positive outcome for many organizations and it is one of the success factors for many organizations. Particularly, tourists' hotels all over the world practice social media to promote its services to the tourists. Therefore, under the marketing communication, social media and its impact on brand equity and purchase intention is discussed. Leung et al., (2013) and Sigala (2011) indicate that the following benefits hotels can get from social media. Social media help understand customers by visiting their profile. It also helps fortify the attempts in marketing and its effectiveness. Social media also helps monitor and control organization image and stimulate demand. Social media is influencing on brand equity positively by influencing on brand awareness and brand image (Schivinski and Dabrowski, 2015). Social media influence on brand image to the larger extent (Bruhn et al., 2012). Further, a study also confirmed that social media communication significantly influences on brand awareness and which affects brand image, brand quality and generating e WOM (Stojanovic et al., 2018). Tourism marketing organizations need to use social media differently according to the requirements of the tourists. Twitter can be used for generating e word of mouth. In order to share photos, Instagram need to be used. YouTube is relevant for tour and guide operators (Moro and Rita, 2018). The literature discussed above confirms that marketing communication through social media influences on brand equity. When a brand or organization is with brand equity, it positively affects customer responses. This is also confirmed that customer-based brand equity elements such as brand loyalty, brand image, perceived quality, and brand awareness positively contribute to the purchase intention (Liu et al., 2017). In addition, brand awareness, brand image, and perceived quality lead to brand loyalty and that in turn, positively affect brand choice intention ( $\mathrm{Lu}$ et al., 2015). Therefore, the researcher hypothesizes the followings;

$\mathrm{H}_{4}$ : Marketing communication of the hotels on the east coast of Sri Lanka contributes to the brand equity of the hotels brand.

$\mathrm{H}_{4 \mathrm{a}}$ : Marketing communication of the hotels on the east coast of Sri Lanka positively affect the customers' response.

Above discussion with literature supports delineate that extended service marketing mix is positively contributing to the brand equity of the hotels and to the customer response towards hotels in the East Coast of Sri Lanka. Brand equity is really leading to the customer response by way of keeping brand awareness, brand image, brand loyalty and perceived quality of the service product. Empirical evidence has also been provided by Buil et al., (2013) to support the following hypothesis. Thus, the researcher hypothesizes that

$\mathrm{H}_{5}$ : Brand equity created from the extended marketing mix positively related to the customer

response of tourists hotel in the East Coast of Sri Lanka

Based on the above discussion of literature, the following conceptual model has been created.

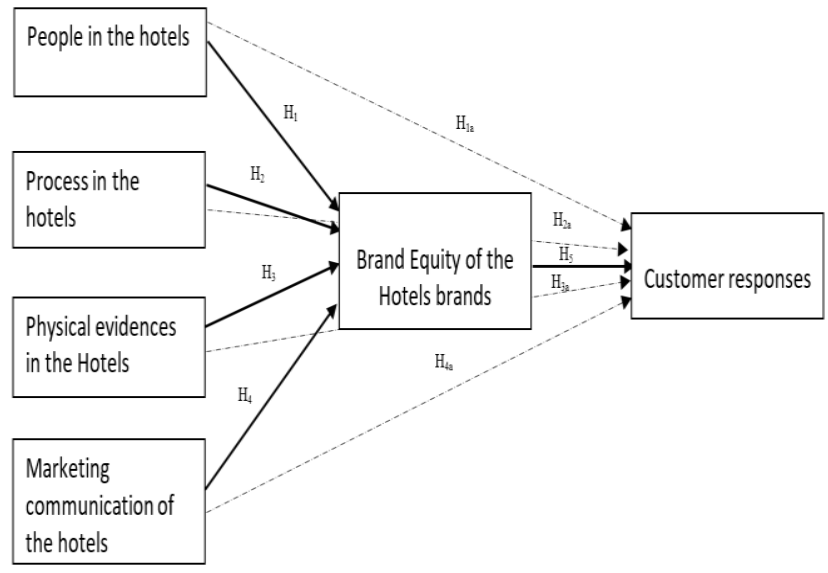

Figure 1: Conceptual Model

\section{METHODOLOGY}

In order to examine the impact of extended marketing mix elements of hotels in the East Coast of Sri Lanka, the researcher conducted a study during the July 2018 to April 2019 in the areas of tourism attractions in three districts Ampara, Batticaloa and Trincomalee. The philosophy of the research was positivism since it involved with the testing of hypotheses with the empirical method. The approach of the

Blue Eyes Intelligence Engineering

\& Sciences Publication 
research is deductive because the study is related to testing a theory developed through conceptual framework supported with previous literature. The research strategy is survey methodology and time horizon was cross-sectional.

\section{Survey Instrument}

The questionnaire for this study has been developed based on previous researchers. All statements in the questionnaire were measured with seven points Likert scale ranging from strongly disagree to strongly agree. Statements for people element were adapted from previous authors. This is shown in Table 1.

Table 1 Items Adaptations

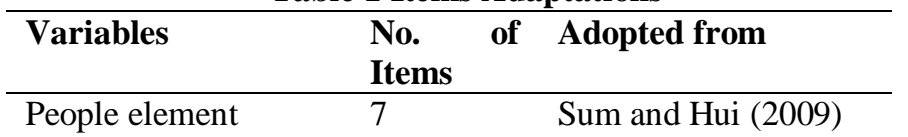

$\begin{array}{lcl}\text { Process element } & 6 & \begin{array}{l}\text { Wirtz and Lovelock } \\ (2016)\end{array} \\ \text { Physical evidence } & 7 & \begin{array}{l}\text { Berman and Evans } \\ (2001)\end{array}\end{array}$

$\begin{array}{lcl}\begin{array}{l}\text { Marketing } \\ \text { communication }\end{array} & 7 & \begin{array}{l}\text { Llodra-Riera et al. } \\ (2015) \\ \text { Magi, (2003), } \\ \text { Tsiros et al., (2004) } \\ \text { Bruhn et al., (2012) }\end{array} \\ \text { Brand equity } & 6 & \begin{array}{l}\text { Yoo and Donthu } \\ (2001)\end{array}\end{array}$

Customer response $\quad 6 \quad$ Ali et al., (2016)

\section{Sample Selection and Data Collection}

As this study needs to explore the impact on the brand equity and customer response, tourists staying in the hotels in the Ampara, Batticaloa, and Trincomalee areas were the appropriate respondents for this study. These areas were selected because improvements in the areas of extended marketing mix elements may be required for these hotels as the areas were affected during the prolonged war in the country. Further, important tourist attraction such as Koneshwaran Temple, clear beach, sea surfing, Pasikudah, Nilavali Beach and Arugamba, etc. are situated in these areas. The researcher visited most of the tourist attractions in three districts during the day time in order to collect the data. Although respondents were hesitant to provide information to fill the questionnaires, the researcher was able to manage receiving information required for the questionnaire. Convenience sampling technique was adopted as the researcher had to meet tourists who were staying in these hotels in three districts mentioned above. In addition, the researcher was able to meet a few tourists inside the hotel premises too. It is also important to point out at this juncture that the researcher asked a question to the respondent before filling questionnaire whether the tourist was staying at the hotel in the area. If yes, tourists were allowed to fill the questionnaire. The researcher was able to get 182 filled questionnaires and ultimately the researcher received 163 duly filled questionnaires. Of the total sample, 31 questionnaires were collected from a tourist in Ampara, 58 from Trincomalee and 74 from Batticaloa district.

\section{RESULTS AND FINDINGS}

Before explaining the statistical analysis, it is important to state the characteristics of the respondents. In the total respondents, 66 percent was male and 34 percent was female. In the case age distribution of the respondents, 11 percent and 22 percent fall in the category of $16-22$ and 23 -34 years of age respectively. The other 36 percent and 31 percent belong to $35-55$ and greater than 55 years of age respectively. While asking about the purpose of visiting a place, 15 percent of respondents said that they visited for an official purpose which include meetings and conferences and businesses. The other 85 percent of the respondents visited for tourism.

\section{RELIABILITY ANALYSIS}

The structural model for this study needs to be validated before obtaining the findings. Cronbatch's Alpha value for all variables is more than 0.7 which means that there is internal consistency exist within the variables.

As per the requirement for structural equation modeling in SmartPLS3, composite reliability should be more than 0.7 (Hair et al., 2013). In this study, the composite reliability is more than 0.7 and therefore, it is reckoned to be reliable. It is also confirmed that convergent validity exists as the average variance extracted is more 0.50 . This is shown in Table 2 .

Table 2 Construct Validity and Reliability

\begin{tabular}{lcccc}
\hline & $\begin{array}{c}\text { Cronbach's } \\
\text { Alpha }\end{array}$ & $\begin{array}{c}\text { rho_A } \\
\text { Reliability }\end{array}$ & $\begin{array}{c}\text { Composite } \\
\text { Average } \\
\text { Variance } \\
\text { Extracted } \\
\text { (AVE) }\end{array}$ \\
\hline Brand equity & 0.896 & 0.903 & 0.936 & 0.829 \\
Customer Response & 0.714 & 0.828 & 0.811 & 0.593 \\
Marketing communication & 0.867 & 0.932 & 0.899 & 0.643 \\
People & 0.856 & 0.924 & 0.887 & 0.567 \\
Physical evidences & 0.890 & 0.924 & 0.918 & 0.657 \\
Process & 0.822 & 0.894 & 0.888 & 0.674 \\
\hline
\end{tabular}

Having confirmed the convergent validity, it is essential to evaluate the model based on Fornel and Larcker criterion in order to confirm the discriminant validity. Table 3 provides the details of Fornel and Larcker criterion. The coefficients are not more than the square root of the average variances extracted. 
Table 3 Fornel and Larcker Criterion

\begin{tabular}{llll}
\hline & BE & CR & MC \\
\hline Brand equity & $\mathbf{0 . 9 1 1}$ & & \\
Customer Response & 0.673 & $\mathbf{0 . 7 7 0}$ & \\
Marketing communication & 0.756 & 0.580 & $\mathbf{0 . 8 0 2}$ \\
People & 0.788 & 0.484 & 0.638 \\
Physical evidences & 0.842 & 0.477 & 0.893 \\
Process & 0.671 & 0.329 & 0.725 \\
\hline
\end{tabular}

Therefore, it can be concluded that the model does not provide evidence of a lack of discriminant validity. Further, the cross-loadings in Table 7 gives evidence of discriminant validity. Factorial loadings of the observed variables are greater than the other. This infers discriminant validity exists in the model.

\section{PATH COEFFICIENT ANALYSIS AND HYPOTHESES TESTING \& RESULTS}

Table 5 gives the model of the direct effect of the extended marketing mix on brand equity and customer response. According to model 1, all three variables such as people, physical evidence and process positively affect the brand equity as its $t$ values are greater than 1.96 and all $p$ values are less than 0.05 . However, the path coefficient for the variable marketing communication is negative but it is significant ( $p<0.05, t>1.96$ ). Therefore, $\mathrm{H}_{1}, \mathrm{H}_{2}$, and $\mathrm{H}_{3}$ are supported in this study. $\mathrm{H}_{4}$ is not supported as it has negative path coefficient.

Table 5 Direct effect of extended marketing mix on Brand equity and Customer Response

\begin{tabular}{|c|c|c|c|c|c|}
\hline & \multirow{2}{*}{\multicolumn{3}{|c|}{$\begin{array}{l}\text { Model 1 } \\
\text { Brand Equity }\end{array}$}} & \multirow{2}{*}{\multicolumn{2}{|c|}{$\begin{array}{l}\text { Model } 2 \\
\text { Customer } \\
\text { Response }\end{array}$}} \\
\hline & & & & & \\
\hline Variable & $\begin{array}{l}\text { Coefficie } \\
\text { nt }\end{array}$ & $\begin{array}{l}t- \\
\text { valu } \\
\text { e }\end{array}$ & $f^{2}$ & $\begin{array}{l}\text { Coefficie } \\
\text { nt }\end{array}$ & $\begin{array}{l}t \quad- \\
\text { valu } \\
\text { e }\end{array}$ \\
\hline People & 0.482 & $\begin{array}{l}8.38 \\
9\end{array}$ & $\begin{array}{l}0.57 \\
6\end{array}$ & 0.324 & $\begin{array}{l}7.66 \\
1\end{array}$ \\
\hline $\begin{array}{l}\text { Physical } \\
\text { evidence }\end{array}$ & 0.421 & $\begin{array}{l}3.41 \\
3\end{array}$ & $\begin{array}{l}0.16 \\
0\end{array}$ & 0.283 & $\begin{array}{l}3.65 \\
1\end{array}$ \\
\hline Process & 0.401 & $\begin{array}{l}6.87 \\
5\end{array}$ & $\begin{array}{l}0.45 \\
0\end{array}$ & 0.274 & $\begin{array}{l}6.47 \\
6\end{array}$ \\
\hline $\begin{array}{l}\text { Marketing } \\
\text { communicati } \\
\text { on }\end{array}$ & -0.223 & $\begin{array}{l}2.06 \\
9\end{array}$ & $\begin{array}{l}0.04 \\
9\end{array}$ & -0.150 & $\begin{array}{l}2.05 \\
7\end{array}$ \\
\hline $\begin{array}{l}\mathrm{R}^{2} \\
\text { Adj. } \mathrm{R}^{2}\end{array}$ & $\begin{array}{l}0.839 \\
0.835\end{array}$ & & & $\begin{array}{l}0.453 \\
0.449\end{array}$ & \\
\hline $\begin{array}{l}f^{2} \text { for Brand } \\
\text { equity } \rightarrow \\
\text { Customer } \\
\text { Response }\end{array}$ & & & $\begin{array}{l}0.82 \\
7\end{array}$ & & \\
\hline
\end{tabular}

According to Model 1 of Table 5, 83.9\% $\left(\mathrm{R}^{2}=0.839\right)$ of the variation of the brand equity of Hotels in the East Coast of Sri Lanka is explained by extended marketing mix such people, physical evidence, process, and marketing communication.
In the case of the effect size of exogenous latent variables orPPhe R'PEyalues BS the endogenous latent variable, according to the Model 1 of Table 5 people elements, physical evidence and process have a significant effect on the $\mathrm{R}^{2}$ value of model 1 . It is also found that marketing communication is insignificantly contributing to the $\mathrm{R}^{2}$ valut5z model 1 . $\mathrm{Q}^{2}$ is 0.651 which is also greater than ze00740d ther8fidre it can be concluded that model accuracy can. be-accepteg 60.821

Model 2 of Table 5 explains the direct effect of extended marketing mix on customer response. As in the Model 1, except marketing communication all other variables such as people, physical evidence, process positively influence on the customer response towards hotels (All ps $\langle 0.05, t\rangle$ 1.96). Further, $44.9 \%$ of the variation in the customer response is explained by the extended marketing mix of the hotels in the East Coast of Sri Lanka. $Q^{2}$ is 0.202 which is also greater than zero and it can be confirmed that the accuracy of the model can be accepted. Therefore, $\mathrm{H}_{1 \mathrm{a}}, \mathrm{H}_{2 \mathrm{a}}$, and $\mathrm{H}_{3 \mathrm{a}}$ are well supported. However, marketing communication is with negative path coefficient and hence, there is no evidence to support the hypothesis $\mathrm{H}_{4 \mathrm{a}}$.

It is also important to test the mediation effect of brand equity of the hotels in the East Coast of Sri Lanka. Table 6 explains the mediation of brand equity between extended marketing mix elements and customer response.

Table 6 Total Effect and Mediating Role of Brand Equity

\begin{tabular}{llll}
\hline & Coefficient & $\begin{array}{l}\text { T } \\
\text { Statistics }\end{array}$ & $\begin{array}{l}\text { P } \\
\text { Values }\end{array}$ \\
\hline $\begin{array}{l}\text { Marketing } \\
\text { communication - }\end{array}$ & -0.150 & 2.101 & 0.036 \\
$>$ Brand equity - & & & \\
$>$ Customer & & & \\
$\begin{array}{l}\text { Response } \\
\text { People -> Brand } \\
\text { equity -> }\end{array}$ & 0.324 & 7.313 & 0.000 \\
$\begin{array}{l}\text { Customer } \\
\text { Response } \\
\text { Physical } \\
\text { evidences -> }\end{array}$ & & & \\
$\begin{array}{l}\text { Brand equity -> } \\
\text { Customer } \\
\text { Response }\end{array}$ & & & \\
$\begin{array}{l}\text { Process -> Brand } \\
\text { equity -> } \\
\text { Customer } \\
\text { Response }\end{array}$ & 0.274 & 3.622 & 0.000 \\
\hline $\begin{array}{l}\text { All } \\
\text { Rariabs }\end{array}$ & & & \\
\hline
\end{tabular}

All variables such as people (Path Coefficient $=0.482, t>$ 1.96, $p<0.05$ ), process (Path Coefficient $=0.407, t>1.96$, $p<0.05$ and physical evidences (Path Coefficient $=0.421, t$ $>1.96, p<0.05)$ positively contribute to the brand equity of the hotels in the East coast of Sri Lanka. It is also evident that these latent variables (People: Path Coefficient $=0.324$, $t>1.96, p<0.05$, Process: Path Coefficient $=0.324, t>$ 1.96, $p<0.05$, Physical evidences: Path Coefficient $=0.283$, $t>1.96, p<0.05$ ) have a positive impact on the customer response. Further, it is also paramount to indicate that brand 
equity of the hotels in the East coast of Sri Lanka significantly contribute to the customer responses towards the hotels (Path Coefficient $=0.673, t>1.96, p<0.05$ ) Marketing communication is with negative path coefficient. Therefore, hypotheses $\mathrm{H}_{1 \mathrm{a}}, \mathrm{H}_{2 \mathrm{a}}$ and $\mathrm{H}_{3 \mathrm{a}}$ are supported and $\mathrm{H}_{4 \mathrm{a}}$ is not supported.

$\mathrm{n}$ the case of brand equity and consumer response, brand equity created by the extended marketing mix positively influence on the consumer response. Therefore, $\mathrm{H}_{5}$ is also supported. Thus, results indicate that brand equity of the hotels partially mediates between the extended marketing mix of the hotels and customer response.

All observed variables are contributing to the latent variables in the model. Factor loadings and its $t$ values are given in Table 7.

Table 7 Factor Loadings

\begin{tabular}{|c|c|c|c|c|}
\hline & $\begin{array}{l}\text { Factor } \\
\text { Loadings }\end{array}$ & T Statistics & P Values & VIF \\
\hline BE1 - Loyal to hotel & 0.945 & 147.322 & 0.000 & 4.087 \\
\hline BE4 - Likely quality of the hotel & 0.867 & 32.129 & 0.000 & 2.223 \\
\hline BE5 - Easy recall of the hotel brand & 0.918 & 83.107 & 0.000 & 3.297 \\
\hline CR1 - Satisfaction of decision to stay at the hotel & 0.641 & 4.272 & 0.000 & 1.523 \\
\hline CR2 - Favorable opinion about a hotel & 0.896 & 47.521 & 0.000 & 1.289 \\
\hline CR4 - Future intention to visit the hotel & 0.751 & 11.665 & 0.000 & 1.471 \\
\hline MC1 - Content of the website help choose hotel & 0.711 & 11.65 & 0.000 & 1.869 \\
\hline MC4 - Social media marketing is attractive & 0.895 & 100.125 & 0.000 & 3.324 \\
\hline MC5 - Social media marketing comparison & 0.869 & 80.836 & 0.000 & 2.075 \\
\hline MC6 - Satisfaction of generated content by others & 0.779 & 24.901 & 0.000 & 1.818 \\
\hline MC7 - Content generated by others are attractive & 0.739 & 16.622 & 0.000 & 2.296 \\
\hline PE1 - Music & 0.950 & 113.335 & 0.000 & 4.321 \\
\hline PE3 - Scent & 0.919 & 56.612 & 0.000 & 3.985 \\
\hline PE4 - Interior and exterior color & 0.838 & 37.223 & 0.000 & 4.173 \\
\hline PE5 - The decoration & 0.520 & 6.572 & 0.000 & 1.690 \\
\hline PE6 - Style of architecture & 0.718 & 32.555 & 0.000 & 2.576 \\
\hline PE7 - Floorspace & 0.841 & 47.697 & 0.000 & 3.040 \\
\hline PP1 - Employees' dress & 0.792 & 21.572 & 0.000 & 4.967 \\
\hline PP3 - Employees provide accurate information & 0.695 & 10.254 & 0.000 & 1.893 \\
\hline PP4 - Employees' knowledge & 0.710 & 12.734 & 0.000 & 4.324 \\
\hline PP5 - Feeling safe while interacting with employees & 0.733 & 15.03 & 0.000 & 2.499 \\
\hline PP6 - Complaints & 0.793 & 51.959 & 0.000 & 1.881 \\
\hline PP7 - Employees' polite and smiling & 0.787 & 23.406 & 0.000 & 2.736 \\
\hline PS1 - Hotel entrance & 0.867 & 31.295 & 0.000 & 3.390 \\
\hline PS2 - Reception set up at the hotel & 0.974 & 157.626 & 0.000 & 4.983 \\
\hline PS3 - Front stage activities & 0.504 & 6.959 & 0.000 & 1.745 \\
\hline PS6 - Pleasure and leisure at hotels & 0.863 & 48.212 & 0.000 & 3.495 \\
\hline
\end{tabular}

Including all $\mathrm{t}$ values and path coefficient are shown in the following structural model. 


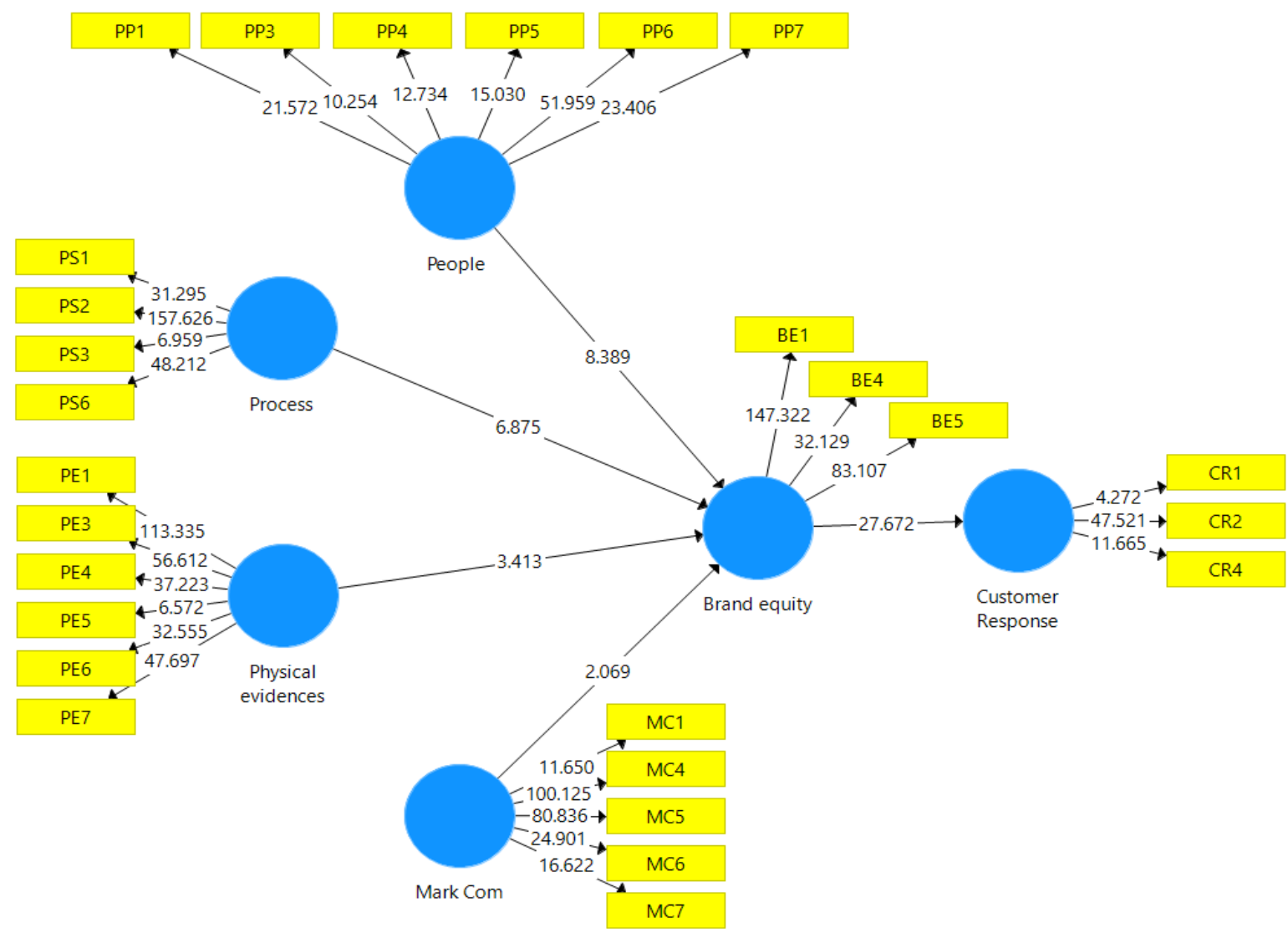

Figure 2 Structural Model

\section{DISCUSSION OF FINDINGS}

The model tested in this study is well supported in spite of the fact that marketing communication has negative path coefficient. People elements, process elements, and physical evidence are positively influencing on the brand equity and customer response of the hotels in the East Coast of Sri Lanka. In the event of mediation of brand equity between extended marketing mix and customer response of these hotels, brand equity has partial mediation. Thus, hotels in the region need to focus on creating brand equity using the elements of the extended service marketing mix. It may give us a greater understanding of the impact the extended marketing mix elements have on the brand equity and customer response of the hotels in the Eastern Province of Sri Lanka by discussing each element.

People element of the extended marketing mix is one of the major variables that impacts on the brand equity and customer response in the hotel industry in the East Coast of Sri Lanka. Complaint handling and employees' responses to the customers are mainly contributing to the people elements. Complaint handling is one of the major factors that determine customer satisfaction as well. Hence, it is essential for these hotels to have a complaint handling system integrated into the process of elements of these hotels in the areas. Moreover, it is also important for the process elements to sustain the pleasant mode of the employees enabling the employees to be polite and smiling with tourists staying in the hotels. Employees' dress is also influencing on the people elements of these hotels that may also provide customers staying in the hotel a feeling of safe while interacting with them.

The second variable which has a major impact on the brand equity and customer response is processes element of the extended marketing mix. Front line staff including employees at the reception areas is mostly influencing and contributing to the process element of the extended marketing mix of hotels. Well set up of reception areas of these hotels in the Eastern Province positively influence on the process element and in turn, significantly contribute to the brand equity and customer response. Due to the service process design of these hotels, customers feel that stay at these hotels is providing pleasure and leisure feeling for them. This, in turn, influence positively on the customer based brand equity and customer response positively. Moreover, it is also found that the front stage activities of these hotels are well organized and serve the customer glowingly as required. Thus, focusing on the front stage operations of the hotels may also help enhance brand equity and in turn, will positively influence the customer response for revisiting to the hotels. 
Thirdly, physical evidence of the extended marketing mix of the hotels in the Eastern region also positively influencing on the brand equity and on the customer response. Factors such as music, attractive scent, architectural style of the building, interior and exterior colors and decoration are contributing to the physical evidence of these hotels and contribute to the brand equity and customer response. Point to the fact that music is one of the major influencing factors in service settings. Music will also be moderated with the characteristics of the customers in the hotels. Some customers will not like to hear fast tempo and high volume music. Within the hotels, it always has soft music which may induce customers' stay during enjoying food as they are staying in the hotels. This may give a feeling of leisure in the hotels. Scents also give a pleasant feeling to the customers in the hotels as one of the ambient factors. The scent provides customers with a mode and shape the behavior of customers inside the hotels and may ensure the customers' repeated visit to the hotels. The next factor in the physical evidence is the color of the interior and exterior of the hotels in the region. The color will have a strong impact on customers' feelings. Therefore, hoteliers need to have their hotels get painted in cool colors than warm colors.

In spite of the fact that marketing communication has a negative impact on the brand equity and purchase intention, hoteliers need much attention on the marketing communication which has a major huge impact on the brand equity and customer response according to the literature. Marketing communication is another variable focusing on the online presence of these hotels impact negatively on the brand equity and customer response. This reflects that these hotels in in the Eastern region of Sri Lanka do not give greater attention to the social media marketing which is now inexpensive for service organizations and is effective in the integrated marketing communication mix. Marketing communication via social media of these hotels should motivate the customers to choose from various hotels and the social media campaign of the customers of these hotels.

\section{CONCLUSION, RECOMMENDATIONS AND MANAGERIAL IMPLICATION}

The major objective of the study was to examine the effect of the elements of extended service marketing mix of the east coast hotels on the creation of the brand equity and customer response. The model with the mediating variable in this study is the best fit and thus, it gives empirical evidence that witnesses extended marketing mix supports customer response mediating through brand equity created by the extended marketing mix of hotels. Findings suggest that brand equity is created by people, process and physical evidence of the extended marketing mix of the hotels. It was also found that created brand equity is partially mediating the relationship between extended marketing mix and customer response. As far as marketing communication via social media is concerned, it does not significantly contribute to the creation of brand equity and in turn, to the customer response. Therefore, it is supreme to adopt the social media promotion for these hotels situated in the East should be attractive and should also meet the expectations

Coast of Sri Lanka in order to derive the brand equity and positive customer responses towards these hotels as the tourist can understand and identify the places better using social media (Stojanovic et al., 2018).

This study also contributes theoretically to the service marketing mix studies. For instant, the current study supports Mokharjee and Shivani (2016) by providing evidence on the creation of brand equity with the usage of extended service marketing mix elements namely people, process and physical evidence. Moreover, this study also sheds light on the creation of brand equity using extended marketing mix of hotels and supports to Rajh (2005) who explains about the influence of the marketing mix (4ps) on the brand equity.

Findings also suggest that people element of these hotels is contributing more to the brand equity and customer response in this study. Therefore, hotels in the region need more attention towards implementing internal marketing activities such as training for the employees on customer care, complaint handlings and service failure and recovery should be given so that their performance may improve further and customers will also be delighted. The process is another major variable that influences positively on the customer response. Service process at the hotels may be required to be improved further in areas of hotel service delivery to make the hotels' environment more leisureoriented and pleasant. Physical evidence are also important for these hotels as it positively impacts on the brand equity and customer response. Music and scents are vital aspects for these hotels in the region. This should be further improved in accordance with the characteristics of the customers stayed in the hotels. Since the scent stimulates the customers, this can also be maintained inside the hotels. Another attribute of the ambiance of hotels is decoration with colors that suit the customers. Colors should be expressive for the customers and may provide a conducive environment to the customers. In the case of marketing communication, hotels need to improve their online presence via social media. Digital marketing is now important source to create brand equity and to positively influence on the customer response. Thus, hoteliers need to develop social media marketing communication in order to further improve the brand equity of these hotels.

This study has limitations on respondents of the questionnaires as the researcher approached tourists who visited Potuvil, Batticaloa, and Trincomalee. These tourists were reluctant to meet and give responses to the study as their language and cultural differences in different settings. Hotels in these areas are not well developed as five-star types of hotels and therefore, the results may be biased. Expanding this type of studies in the future for other areas where we may find five-star types of hotels. It may give more meaningful findings for this study. Further, future studies may be focused on brand equity elements such as brand awareness, brand image, perceived quality of services and brand knowledge about the services provided by the hotels and its impact on the customers' revisit intention. 


\section{REFERENCES}

1 Abril, C., Canovas, B.R. (2012), Marketing Mix Effects on Private Labels Brand Equity, European Journal of Management and Business Economics, Vol. 25, pp. 168175.

2 Abu-ELSamen A.A, Akroush M.N, Al-Khawaldeh F.M, Al-Shibly M.S, (2011), Towards an Integrated Model of Customer Service Skills and Customer Loyalty: The Mediating Role of Customer Satisfaction, International Journal of Commerce and Management, Vol. 21, No. 4, pp.349-380.

3 Aghaei, M., Vahedi., Kahreh M.S., and Pirooz, M. (2014), An Examination of the Relationship between Services Marketing Mix and Brand Equity Dimensions, Procedia - Social and Behavioural Sciences, Vol. 109, pp. $865-869$

4 Albrecht C.M, Hattula S, Bornemann T, Hoyer W.D, (2016), Customer Response to Interactional Service Experience: The Role of Interaction Environment, Journal of Service Management, Vol. 27, No. 5, pp.704729.

5 Ali, F., Hussain, K. and Omar, R. (2016), Diagnosing Customer Experience, Emotions and Satisfaction in Malaysian Resort Hotels, European Journal of Tourism Research, Vol. 12, pp. 25-40.

6 Ali, F., Omar, R. and Amin, M. (2013), An examination of the Relationships between Physical Environment, Perceived Value, Image and Behavioural Intentions: A SEM Approach towards Malaysian Resort Hotels, Journal of Hotel and Tourism Management, Vol. 27, No. 2, pp. 9-26.

7 Andreassen T.W, Kristensson P, Olsen L.L, Parasuraman A, McColl-Kennedy J.R., Edvardsson B, Colurcio M, (2016), Linking Service Design to Value Creation and Service Research, Journal of Service Management, Vol. 27, No. 1, pp.21-29.

8 Baron, R.M., and Kenny, D.A. (1986), The ModeratorMediator Variable Distinction in Social Psychological Research: Conceptual, Strategic and Statistical Consideration, Journal of Personality and Social Psychology, Vol. 51, No. 6, pp. 1173-1182.

9 Beltagui A, Candi M, (2018), Revisiting Service Quality through the Lens of Experience Centric Services, International Journal of Operations \& Production Management, Vol. 38, No. 3, pp.915-932.

10 Berman, B. and Evans, J.R. (2001), Retail Management: A Strategic Approach, 12th ed., Pearson International Edition.

11 Bitner, M., Ostrom, A., Morgan, F. (2008), Service Blueprinting: A Practical Technique for Service Innovation, California Management Review, Vol. 50 No. 3, pp. 66-94.

12 Bravo R, Martinez E, Pina J.M, (2019), Effects of Service Experience on Customer Responses to a Hotel Chain, International Journal of Contemporary Hospitality Management, Vol. 31, No. 1, pp.389-405.

13 Bruhn, M., Schoenmueller, V. and Schafer, D.B. (2012), Are Social Media Replacing Traditional Media in terms of Brand Equity Creation?, Management Research Review, Vol. 35 No. 9, pp. 770-790.

14 Buil I., Martinez, E., Chernatony., L.D. (2013), The Influence of Brand Equity on Consumer Responses, Journal of Consumer Marketing, Vol. 30, No. 1, pp. 6274

15 Caruana. A., Calleya P., (1998), The Effect of Internal Marketing on Organizational Commitment among Retail Bank Managers, International Journal of Bank Marketing, Vol. 16, No. 3, pp.108-116

16 Choudhury K., (2013), Service Quality and Customers' Purchase Intentions: An Empirical Study of the Indian Banking Sector, International Journal of Bank Marketing, Vol. 31, No.7, pp.529-543

17 Contiero E, Ponsignon F, Smart P.A, Vinelli A, (2016), Contingencies and Characteristics of Service Recovery System Design: Insights from Retail Banking, International Journal of Operations \& Production Management, Vol. 36, No. 11, pp.1644-1667

18 Cretu, A. E., \& Brodie, R. J. (2007). The Influence of Brand Image and Company Reputation where Manufacturers Market to Small Firms: A Customer Value Perspective, Industrial Marketing Management, Vol. 36, No. 2, pp. 230-240.

19 Erdem, T., Swait, J., and Valenzuela, A. (2006), Brands as Signals: A Cross-Country Validation Study, Journal of Marketing, Vol. 70, No. 1, pp. 34-49.

20 Hanaysha J.R, (2018), An Examination of the Factors Affecting Consumer's Purchase Decision in the Malaysian Retail Market, PSU Research Review, Vol. 2, No. 1, pp.7-23

21 Hair, J.F., Hult, G.T.M., Ringle, C.M., Sarstedt, M., (2013), A Primer on Partial Least Squares Structural Equation Modeling (PLS-SEM). Sage, Thousand Oaks

22 Hernandez M.I.S., Miranda F.J, (2011), Linking Internal Market Orientation and New Service Performance, European Journal of Innovation Management, Vol. 14, No.2, pp.207-226.

23 Horng J.S., Liu C.H., Tsai C.Y. (2012), Understanding the Impact of Culinary Brand Equity and Destination Familiarity on Travel Intentions, Tourism Management, Vol. 33, pp. 815-824.

24 Huang R., Sarigollu E., (2012), How Brand Awareness Relates to Market Outcome, Brand Equity and the Marketing Mix, Journal of Business Research, Vol. 65, No. 1, pp. 92-99.

$25 \mathrm{Hu} \mathrm{H}$, Jasper C.R, (2006), Social Cues in the Store Environment and their Impact on Store Image, International Journal of Retail \& Distribution Management, Vol. 34, No. 1, pp.25-48.

26 Jones T, Fox G.L, Taylor S.F, Fabrigar L.R, (2010), Service Customer Commitment and Response, Journal of Services Marketing, Vol. 24, No. 1, pp.16-28.

27 Keller, K. L. (1993). Conceptualizing, Measuring, and Managing Customer-Based Brand Equity, Journal of Marketing, Vol. 57, No. 1, pp. 1-22.

28 Keller, K.L. (2013), Strategic brand management: building, measuring, and managing brand equity, $\left(4^{\text {th }}\right.$ ed.), Pearson, England

29 Kimpakorn N., Tocquer G, (2010), Service Brand Equity and Employee Brand Commitment, Journal of Services Marketing, Vol. 24, No. 5, pp.378-388.

30 Kostopoulos G, Gounaris S, Boukis A, (2012), Service Blueprinting Effectiveness: Drivers of Success, Managing Service Quality: An International Journal, Vol. 22, No. 6, pp.580-591

31 Larsen P, Tonge R, Lewis A, (2007), Strategic Planning and Design in the Service Sector, Management Decision, Vol. 45, No. 2, pp.180-195.

32 Leung, D., Law, R., van Hoof, H. and Buhalis, D. (2013), Social Media in Tourism and Hospitality: A Literature Review, Journal of Travel \& Tourism Marketing, Vol. 30 No. $1 / 2$, pp. $3-22$.

33 Liu M.T, Wong I.A, Tseng T.H, Chang A.W., Phau I. (2017), Applying Consumer Based Brand Equity in Luxury Hotel Branding, Journal of Business Research, 81 , pp. $192-202$ 
34 Llodra-Riera, I., Martínez-Ruiz, M.P., Jiménez-Zarco, A.I. and Izquierdo-Yusta, A. (2015), A Multidimensional Analysis of the Information Sources Construct and Its Relevance for Destination Image Formation, Tourism Management, Vol. 48, pp. 319-328.

35 Lu, A.C.C., Gursoy, D., Lu, C.Y. (2015), Authenticity Perceptions, Brand Equity and Brand Choice Intention: The Case of Ethnic Restaurants, International Journal of Hospitality Management, Vol. 50, pp. 36-45.

36 Mager, B. (2004), Service Design - A Review, Prima Print, Koeln.

37 Magi, A.W. (2003), Share of Wallet in Retailing: the Effects of Customer Satisfaction, Loyalty Cards and Shopper Characteristics, Journal of Retailing, Vol. 79 No. 2, pp. 97-106.

38 Mahmood, R. and Khan, S.M. (2014), Impact of Service Marketing Mixes on Customer Perception: A Study on Eastern Bank Limited, Bangladesh, European Journal of Business and Management, Vol. 6 No. 34, pp. 164-167.

39 Mattila A.S, Wirtz J (2008), The Role of Store Environmental Stimulation and Social Factors on Impulse Purchasing, Journal of Services Marketing, Vol. 22, No. 7, pp.562-567.

40 Mohan G, Sivakumaran B, Sharma P, (2013), Impact of Store Environment on Impulse Buying Behavior, European Journal of Marketing, Vol. 47, No. 10, pp.1711-1732.

41 Moro S, Rita P, (2018), Brand Strategies in Social Media in Hospitality and Tourism, International Journal of Contemporary Hospitality Management, Vol. 30, No.1, pp.343-364.

42 Mukharjee, S., Shivani, S. (2016), Marketing Mix Influence on Service Brand Equity and Its Dimensions, Vision, Vol. 20, No. 1, pp. 9-23.

43 Oh, J., Fiorito, S.S., Cho, H. and Hofacker, C.F. (2008), Effects of Design Factors on Store Image and Expectation of Merchandise Quality in Web-based Stores, Journal of Retailing and Consumer Services, Vol. 15, No. 4, pp. 237-249.

44 Papasolomou. I, Vrontis, D., (2006), Building Corporate Branding through Internal Marketing: The Case of the UK Retail Bank Industry, Journal of Product \& Brand Management, Vol. 15, No.1, pp.37-47.

45 Rajh, E. (2005), The Effect of Marketing Mix Elements on Brand Equity, Economic Trends and Economic Policy, No. 102, pp. 30-59.

46 Ramanathan U, Subramanian N, Parrott G, (2017), Role of Social Media in Retail Network Operations and Marketing to Enhance Customer Satisfaction, International Journal of Operations \& Production Management, Vol. 37, No.1, pp.105-123

47 Rauch D.A, Collins M.D, Nale R.D, Barr P.B, (2015), Measuring Service Quality in Mid-Scale Hotels, International Journal of Contemporary Hospitality Management, Vol. 27, No. 1, pp.87-106

48 Sachdeva I, Goel S, (2015), Retail Store Environment and Customer Experience: A Paradigm, Journal of Fashion Marketing and Management, Vol. 19, 3, pp.290298

49 Schivinski B, Dabrowski D, (2015), The Impact of Brand Communication on Brand Equity through Facebook, Journal of Research in Interactive Marketing, Vol. 9, No.1, pp.31-53.

50 Seo, E.J. and Park, J.W. (2018), A Study on the Effects of Social Media Marketing Activities on Brand Equity and Customer Response in the Airline Industry, Journal of Air Transport Management, Vol. 66, pp. 36-41.

51 Sheu C, McHaney R, Babbar S, (2003), Service Process Design Flexibility and Customer Waiting Time, International Journal of Operations \& Production Management, Vol. 23, No. 8, pp.901-917
52 Sigala, M. (2011), eCRM 2.0 Applications and Trends: the Use and Perceptions of Greek Tourism Firms of Social Networks and Intelligence, Computers in Human Behavior, Vol. 27, pp. 655-661.

53 Sivadas E., Prewitt, J.L.B, (2000), An Examination of the Relationship between Service Quality, Customer Satisfaction, and Store Loyalty, International Journal of Retail \& Distribution Management, Vol. 28, No. 2, pp.73-82.

54 Smith J, Anderson S, Fox G, (2017), A Quality System's Impact on the Service Experience, International Journal of Operations \& Production Management, Vol. 37, No. 12, pp.1817-1839.

55 Stojanovic I, Andreu L, Curras-Perez R, (2018), Effects of the Intensity of Use of Social Media on Brand Equity: An Empirical Study in a Tourist Destination, European Journal of Management and Business Economics, Vol. 27, No. 1, pp.83-100.

56 Sum C.Y, Hui C.L, (2009), Salespersons' Service Quality and Customer Loyalty in Fashion Chain Stores: A Study in Hong Kong Retail Stores, Journal of Fashion Marketing and Management: An International Journal, Vol. 13, No. 1, pp.98-108

57 Tsiros, M., Mittal, V. and Ross, W.T. Jr. (2004), The Role of Attributions in Customer Satisfaction: a Reexamination, Journal of Consumer Research, Vol. 31, No. 2, pp. 476-483.

58 Wirtz J, Mattila A.S, Tan R.L.P, (2007), The Role of Arousal Congruency in Influencing Consumers Satisfaction Evaluations and In-store Behaviors, International Journal of Service Industry Management, Vol. 18, No. 1, pp.6-24.

59 Wirtz., J. and Lovelock., C. (2016), Services Marketing, ( $8^{\text {th }}$ ed. $)$, Pearson, USA

60 Wong A, Sohal A, (2003), Service Quality and Customer Loyalty Perspectives on Two Levels of Retail Relationships, Journal of Services Marketing, Vol. 17 No. 5, pp.495-513.

61 Xie K.L, Zhang Z, Zhang Z, Singh A, Lee S.K, (2016), Effects of Managerial Response on Consumer eWOM and Hotel Performance: Evidence from TripAdvisor, International Journal of Contemporary Hospitality Management, Vol. 28, No. 9, pp.2013-2034

62 Yang H, Coates N, (2010), Internal Marketing: Service Quality in Leisure Services, Marketing Intelligence \& Planning, Vol. 28, No. 6, pp.754-769.

63 Yoo B, Donthu N (2001), Developing and Validating a Multidimensional Consumer-Based Brand Equity Scale, Journal of Business Research, Vol. 52, pp. 1 -14.

64 Yoo, B., Donthu, N., \& Lee, S. (2000), An Examination of Selected Marketing Mix Elements and Brand Equity, Journal of the Academy of Marketing Science, Vol. 28, No. 2, pp. 195-211.

65 Zolfagharian M, Hasan F, Iyer P, (2018), Customer Response to Service Encounter Linguistics, Journal of Services Marketing, Vol. 32, No. 5, pp.530-546. 